\title{
है \\ VISUALISASI AMUK MASSA \\ (Analisis Framing Berita Online Kasus Aksi Massa \\ Kepada Pencuri Amplifier Masjid di Kabupaten Bekasi)
}

\author{
Farid Pribadi., M.Sosio \\ Program Studi Sosiologi FISH Universitas Negeri Surabaya \\ Email:faridpribadi@unesa.ac.id
}

\begin{abstract}
Abstrak
Peristiwa tindak kekerasan masih menjadi bahan berita menarik oleh beberapa media massa online. Salah satunya peristiwa amuk massa kepada pencuri amplifier masjid di Kabupaten Bekasi yang berhasil diliput dan dijadikan headline news tribunjogja.com dan grid.id. Namun, setelah dianalisis menggunakan analisis framing model Robert Entman hasilnya sungguh memprihatinkan. Dengan dalih ingin memberitakan berita apa adanya, aksi brutal massa dan penderitaan korban dieksplotasi melalui teknik penyusunan kata-kata yang dramatis, vulgar dan sadistik disertai penayangan gambar detail kondisi korban. Visualisasi kekerasan semacam ini adalah upaya media massa untuk meningkatkan popularitas media sekaligus maksimalisasi profit. Pemberitaan kekerasan dalam perkembangannya menjadi paradoks. Di satu sisi meningkatkan kewaspadaan masyarakat terhadap bentuk tindak kriminalitas yang ada di sekelilingnya. Namun di sisi lain, pemberitaan kekerasan berupa amuk massa yang bernuansa menyeramkan tersebut justru dapat menakut-nakuti masyarakat bahkan justru dapat memberikan inspirasi bagi beberapa orang untuk melakukan tindakan serupa. Akhirnya gaya pemberitaan semacam ini justru menimbulkan praktik kekerasan simbolik.
\end{abstract}

Kata Kunci : Amuk Massa, Headline News, Analysis Framing, Kekerasan Simbolik

\begin{abstract}
Violent incidents are still subject to news by some online mass media. One of the mass amok events to thieves amplifier mosque in Bekasi Regency that successfully covered and made headline news tribunjogja.com and grid.id. However, after analyzed using framing analysis model Robert Entman the result is really apprehensive. Under the pretext of telling the news as it is, the brutal action of the masses and the suffering of the victims are exploited through the dramatic, vulgar and sadistic technique of composing words with the detail picture of the victim's condition. Such violent visualization is a mass media effort to increase media popularity while maximizing profit. The proliferation of violence in its development becomes paradoxical. On the one hand raising public awareness of the form of crime that surrounds it. But on the other hand, the news of violence in the form of a terrible amalgam of the masses can actually frighten the community even it can inspire some people to perform similar actions. Finally, this style of preaching leads to the practice of symbolic violence.
\end{abstract}

Keywords : Mass Brutal Action, Headline News, Analisis Framing, Symbolic Violence 


\section{LATAR BELAKANG}

Kekerasan adalah salah satu fenomena yang masih sering dijumpai di tengah-tengah masyarakat. Wujud tindak kekerasan antara lain pemukulan, bentrokan fisik, pembunuhan, mutilasi dan aksi massa. Tindak kekerasan semacam ini kemudian diliput dan diberitakan oleh media massa sehingga kekerasan yang terjadi di satu tempat dapat dengan mudah dan cepat diketahui oleh masyarakat di tempat lain. Misalnya berita aksi massa terhadap pria terduga mencuri ampliier masjid di Kabupaten Bekasi yang disebarkan melalui media massa online.

Diceritakan seorang pria berinisal MA dibakar hidup-hidup setelah dituduh mencuri amplifier Mushala Al-Hidayah di Babelan, Kabupaten Bekasi. Menurut salah seorang warga yang menyaksian kejadian pembakaran tersebut mengatakan MA sempat berteriak bahwa dia tidak bersalah. Namun, ucapan MA tidak dipercayai massa. Massa tetap menghakimi MA berulang kali dengan dasar "maling mana ada mau ngaku" hingga akhirnya MA tewas.

Dengan dalih ingin menyampaikan informasi apa adanya, media massa telah mempertontonkan tindak kekerasan kepada publik. Peristiwa yang mampu memacu emosi salah satunya aksi maling amplifier diuraikan gamblang melalui tulisan dan foto. Gaya penulisan berita berdarah-darah, kejar-kejaran, pemukulan dan air mata menjadi unsur penting diangkat dalam pemberitaan. Dengan pemberitaan tersebut, media massa berharap mampu menjadi magnet perhatian publik sehingga popularitas media akan meningkat. Kasus-kasus aksi massa semacam ini terkadang dijadikan sebagai headline sejumlah media massa.

Pemberitaan kekerasan dalam perkembangannya menjadi paradoks. Di satu sisi meningkatkan kewaspadaan masyarakat terhadap bentuk tindak kriminalitas yang ada di sekelilingnya. Namun di sisi lain, pemberitaan kekerasan berupa amuk massa yang bernuansa keengerian tersebut justru dapat menakut-nakuti masyarakat. Bahkan lebih jauh lagi, pemberitaan kekerasan dapat memberikan inspirasi bagi beberapa orang untuk melakukan tindakan serupa.

Berdasarkan uraian problematika pemberitaan media massa diatas maka penelitian ini mengajukan rumusan masalah bagaimana media massa online tribunjogja.com dan grid.id membingkai (frame) pemberitaan headline (headline news) tentang tindakan aksi massa terhadap oknum pencuri amplifier masjid di Kabupaten Bekasi. Adapun tujuan penelitian ini adalah untuk mengambarkan, menganalisis dan memahami cara tribunjogja.com dan grid.id membingkai (frame) pemberitaan headline (headline news) tindakan aksi massa terhadap oknum pencuir amplifier masjid di Kabupaen Bekasi.

Selanjutnya memilih media massa online (dibandingkan dengan media massa cetak maupun elektronik) karena memliki keunggulan dalam hal kecepatan menyebarkan informasi sebuah peristiwa kepada masyarakat (Romli dan Syamsul, 2012).

\section{METODE PENELITIAN}

Penelitian ini menggunakan pendekatan kualitatif. Kualitatif merupakan prosedur penelitian yang bertujuan mendapatkan gambaran utuh dalam memaknai suatu peristiwa (meliputi kata-kata tertulis atau lisan) dari individu-individu yang dapat diamati. Selanjutnya sifat penelitian yang didasarkan pada tujuan penelitian ini adalah penelitian deskriptif. Penelitian deskriptif menyediakan gambaran utuh tentang konteks, situasi dan kejadian peristiwa atau fenomena dari apa yang diamati.

Unit analisis dalam penelitian ini adalah artikel headline berita online tentang aksi massa terhadap pria terduga mencuri amplifier masjid di 
Kabupaten Bekasi, Jawa Barat, Selasa 1 Agustus 2017 yang dimuat di media massa online tribunnews.com (http://jogja.tribunnews.com/ 2017/08/02/sadis-pria-di-bekasi-tewas-dibakarkarena-diduga-mencuri-ampli-masjid-ternyatasalah-sasaran?page=all) dan grid.id (http://www.grid.id/w-stories-w-news/2017/08/02/ ngeri-pria-di-bekasi-ini-dikira-maling-dandibakar-hidup-hidup-padahal-tukang-servishabis-sholat?page $=$ all)

Headline berita (headline news) merupakan berita utama yang memiliki ciri-ciri diantaranya aktual (up to date), informatif, menarik, dan menonjolkan satu berita dengan dukungan teknik grafis atau foto-foto peristiwa tertentu sehingga diharapkan mampu menarik pembaca agar menyelesaikan bacaan beritanya sampai tuntas. Letak headline berita di media cetak umumnya berada di halaman depan, ditandai dengan pemberian judul berukuran huruf (font) headline lebih besar dibandingkan judul berita lainnya serta didukung oleh foto master yang menggambarkan peristiwa atau kejadian dramatis. Sementara khusus di media online, headline berita ditempatkan pada unggahan berita pertama kali diunggah berdasarkan waktu jam, menit dan detik.

Selanjutnya penelitian ini menggunakan analisis framing. Analisis framing secara sederhana dapat digambarkan sebagai analisis untuk mengetahui bagaimana realitas sosial (peristiwa, aktor, kelompok atau apa saja) dimaknai dan dikonstruksi dengan makna tertentu. Lebih lanjut, menurut Eriyanto menjelaskan analisis framing adalah salah satu metode analisis teks yang berada dalam kategori penelitian konstruksionis. Paradigma ini memandang realitas kehidupan sosial bukanlah realitas yang natural, tetapi hasil dari konstruksi. Jadi setiap media massa dapat berbeda-beda dalam mengkonstruksikan isu yang terjadi. Karenanya, konsentrasi analisis paradigma konstruksionis adalah menemukan bagaimana peristiwa atau realitas tersebut dikonstruksi dan dengan cara apa konstruksi tersebut dibentuk (Eriyanto 2002, 11).

Penganut konstruksionis melihat wartawan bukanlah robot yang bertugas meliput apa adanya melainkan berdasarkan etika, moral dan ideologi tertentu. Wartawan bukan hanya sebagai pelapor atau meng-copy paste realitas yang riil, karena disadari atau tidak ia telah menjadi partisipan dari keragaman penafsiran dan subjetivitas individu. Oleh karena fungsinya tersebut, maka wartawan menulis berita bukan hanya sebagai penjelas, tetapi juga mengkonstruksi peristiwa melalui dirinya sendiri dengan realitas yang diamatinya.

Analisis framing yang digunakan dalam penelitian ini model Robert Entman. Entman melihat framing dalam dua dimensi besar yaitu seleksi isu dan penekanan atau penonjolan aspek-aspek tertentu dari realitas atau isu (Eriyanto, 2002:187). Seleksi Isu, adalah aspek yang berhubungan dengan pemilihan fakta. Dari realitas yang kompleks dan berragam itu, berita mana yang diseleksi dalam pemberitaan tindak aksi massa untuk ditampilkan kepada khayalak? Dari proses ini terkandung didalamnya ada bagian berita yang dimasukkan (included), tetapi ada juga berita yang dikeluarkan (excluded). Dengan demikian tidak semua aspek atau bagian dari berita aksi massa tersebut ditampilkan, wartawan memilih dan memilah berita tertentu yang dianggap penting oleh khalayak.

Penonjolan Aspek Tertentu Dari Isu, aspek ini berhubungan dengan penulisan fakta. Hal ini berkaitan dengan pemakaian kata, kalimat, gambar, dan citra tertentu untuk ditampilkan pada khalayak. Tujuan penonjolan aspek tertentu semacam ini adalah ingin membatasi sekaligus mengarahkan persepsi khalayak terhadap berita aksi massa yang ditulis.

Selanjutnya analisis framing dengan model Entman melalui empat perangkat yaitu pertama, Define Problems (Definisi Masalah). Ini berkaitan 
bagaimana bingkai utama (master frame) suatu masalah/isu dilihat/dimaknai secara berbeda/khas oleh wartawan?

Kedua, Diagnose Cause (perkiraan masalah dari sumber masalah). Ini berkaitan dengan apa penyebab dari suatu masalah, siapa aktor yang dianggap sebagai penyebab peristiwa? Dengan kata lain, pendefinisian sumber masalah ini menjelaskan siapa yang dianggap sebagai pelaku dan siapa yang menjadi korban dalam kasus tersebut.

Ketiga, Make Moral Judgement (pembuatan keputusan moral). Ini berkaitan nilai moral apa yang akan disajikan untuk menjelaskan masalah? Nilai moral apa yang dipakai untuk melegitimasi suatu tindakan? Elemen framing yang dipakai untuk membenarkan/memberi argumentasi pada pendefinisian masalah yang telah dibuat. Gagasan yang dikutip berhubungan dengan sesuatu yang familiar atau dikenal oleh khalayak.

Keempat, Treatment Recommendation (penyelesaian masalah). ini berkaitan tentang penyelesaian apa yang ditawarkan untuk mengatasi masalah/isu? Jalan apa yang ditempuh untuk mengatasi masalah. Elemen ini dipakai untuk menilai apa yang dikehendaki oleh wartawan terkait cara apa yang dipilih untuk menyelesaikan masalah. Penyelesaian itu tentu saja sangat tergantung pada bagaimana peristiwa itu dilihat dan siapa yang dipandang sebagai penyebab masalah.

\section{PEMBAHASAN}

\section{Hasil Framing Terhadap Berita Tribunjogja.com}

Tribunjogja.com memberikan judul berita 'SADIS! Pria di Bekasi Tewas Dibakar Karena Diduga Mencuri Ampli Masjid' pada tanggal 2 Agustus 2017 pukul 16.50 WIB. Berita yang diletakkan di rubrik Viral Medsos ini menyuguhkan ulasan beberapa akun facebook netizen yang menampilkan berisikan video dan gambar foto
Tabel Hasil Analisis Framing Robert Entman

\begin{tabular}{|c|c|c|}
\hline & www.tribunjogja.com & www.grid.id \\
\hline Judul & $\begin{array}{l}\text { 'SADIS! Pria di Bekasi } \\
\text { Tewas Dibakar Karena } \\
\text { Diduga Mencuri Ampli } \\
\text { Masjid'. }\end{array}$ & $\begin{array}{l}\text { Ngeri, Pria di Bekasi Ini } \\
\text { Dikira Maling dan } \\
\text { Dibakar Hidup-Hidup, } \\
\text { Padahal Tukang Servis } \\
\text { Habis Sholat }\end{array}$ \\
\hline $\begin{array}{l}\text { Define } \\
\text { Problems }\end{array}$ & $\begin{array}{l}\text { Cara mengungkap } \\
\text { kebenaran siapa yang } \\
\text { mencuri amplifier masjid }\end{array}$ & $\begin{array}{l}\text { Korban salah sasaran } \\
\text { amuk massa dan MA } \\
\text { bukan }\end{array}$ \\
\hline $\begin{array}{l}\text { Diagnose } \\
\text { Cause }\end{array}$ & $\begin{array}{l}\text { MA adalah korban aksi } \\
\text { massa dan MA adalah } \\
\text { pelaku pencurian }\end{array}$ & $\begin{array}{l}\text { MA disangka membawa } \\
\text { ampli milik masjid saat } \\
\text { menuju keluar dari masjid }\end{array}$ \\
\hline $\begin{array}{l}\text { Make Moral } \\
\text { Judgement }\end{array}$ & $\begin{array}{l}\text { Pernyataan Kapolres } \\
\text { Metro Bekasi, Kombes } \\
\text { Asep Adi Saputra bahwa } \\
\text { MA adalah pelaku } \\
\text { pencurian }\end{array}$ & $\begin{array}{l}\text { Tidak ada sumber } \\
\text { kutipan resmi. Namun } \\
\text { diilustrasikan bahwa MA } \\
\text { bukan pelaku pencurian }\end{array}$ \\
\hline $\begin{array}{l}\text { Treatment } \\
\text { Recommendation }\end{array}$ & $\begin{array}{l}\text { Proses penyelidikan dari } \\
\text { kepolisian menyatakan } \\
\text { MA adalah pelaku } \\
\text { pencurian. } \\
\text { Keterangan koreksi } \\
\text { redaksi terkait MA semula } \\
\text { korban salah sasaran } \\
\text { berganti menjadi tersangka. }\end{array}$ & $\begin{array}{l}\text { Hasil penelusuran dan } \\
\text { pemeriksaan lokasi } \\
\text { kejadian MA bukanlah } \\
\text { seorang pencuri sebab } \\
\text { amplifier tidak hilang }\end{array}$ \\
\hline
\end{tabular}

diantaranya aksi massa, foto korban, hingga prosesi pemakaman jenazah korban. Beberapa akun facebook (FB) yang dijadikan sumber berita diantaranya akun facebook bernama Yuni Rusmini dan Bobby Brandkill Merch.

Melalui dua akun FB tersebut wartawan tribunnews.com mengulas detail isi video viral kebringasan aksi massa terhadap oknum pencuri amplifier sebuah Masjid di Desa Muara Bakti Kecamatan Babelan Kabupaten Bekasi Jawa Barat. Diceritakan bahwa pria berinisial MA yang berprofesi sebagai tukang servis televisi hendak shalat ashar di Masjid di Desa Muara Bakti. MA kemudian mambawa amplifier miliknya tersebut kedalam masjid karena khawatir akan hilang jika diletakkan diatas jok motor. Namun, usai shalat MA ingin memasukkan amplifier kedalam motor MA justru disangka telah mencuri amplifier masjid. MA kemudian mencoba berlari ke kampung lain namun usahanya gagal. Warga berhasil menangkap dan langsung menghakimi bahkan membakarnya 
hidup-hidup. MA akhirnya meninggal dilokasi kejadian dengan luka parah tanpa ada yang menolong.

Melalui dua akun (Yuni Rusmini dan Bobby Brandkill Merch) pula tribunjogja.com juga berhasil menguraikan bahwa MA merupakan bukan pelaku pencurian amplifier. Sebab setelah diperiksa ternyata amplifier masih ada didalam masjid. Pihak keluarga korban hanya isa pasrah dan hanya bisa memaafkan serta tidak ingin memperkarakan atas aksi main hakim sendiri tersebut. Korban salah sasaran ini kemudian memicu sejumlah netizen untuk menyampaikan aksi simpati bahkan mengutuk aksi main hakim sendiri.

\section{Astagfirullahhaladzim}

Ternyata korban adalah salah tuduh yang dijadikan korban kebrutalan manusia yang dirasuki iblis. Biadap...pelakunya..

Ya Allah...

Smg husnul khotimah ya pak...orang-orang yang telah mendzolimi dan melakukan tindakan keji pada bapak semoga mendapat hidayah atas tindakannya. Buat keluarga bapak almarhum yang ikhlas dan sabar nggih... Semoga ada berkah di balik musibah ini ... amin yarroball alamin.

Tribunjogja.com juga menurunkan sub judul berita 'Polisi Benarkan MA Pencuri Pengeras Suara'. Sub judul ini berisi pernyataan resmi dari Kapolres Metro Bekasi, Kombes Asep Adi Saputra bahwa setelah proses penyelidikan pria berinisial MA adalah pelaku pencuri amplifier masjid. Pernyataan Kombes Asep tersebut diperoleh tribunjogja.com melalui kutipan berita Warta Kota (Warta Kota adalah media massa yang masih dalam satu manajemen tribunews.com) MA terpergok warga mencuri amplifier kemudian berlari lalu menceburkan diri ke sebuah kali sampai akhirnya dihakimi massa dan dibakar hidup-hidup.
Pemberian sub judul berita 'Polisi Benarkan MA Pencuri Pengeras Suara' adalah upaya tribunjogja.com untuk melakukan klarifikasi atas informasi yang beredar bahwa MA bukan pelaku pencurian. Selanjutnya, ilustrasi pernyataan resmi dari kepolisian tersebut sekaligus memberikan klarifikasi berupa koreksi dari redaksi tribunjogja.com. Pemberian keterangan *Koreksi redaksi menandakan ada kesalahan dalam pemberitaan yang kemudian dilakukan upaya klarifikasi dari pihak tribunjogja.com.

Tribunjogja.com juga menampilan 4 (empat) foto berita yang dikutip dari akun facebook milik Yuni Rusmini dan Bobby Brandkill Merch. Foto berita berupa gambar MA (yang sudah dikaburkan/diblur) tewas akibat amuk massa dan foto prosesi pemberangkatan pemakaman MA yang diletakkan di awal berita, ditengah atau di sela-sela uraian paragraf berita.

\section{Hasil Framing Terhadap Berita www.grid.id}

Grid.id dalam memberitakan kasus aksi massa pada Rabu tanggal 2 Agustus 2017 pukul 23.52 WIB tersebut tidak ada sama sekali sumber resmi yang dimintai keterangan. Grid.id memberikan judul Ngeri, Pria di Bekasi Ini Dikira Maling dan Dibakar Hidup-Hidup, Padahal Tukang Servis Habis Sholat.

Berbekal postingan dari akun facebook (FB) milik Aris Riswandi dan Yuni Rusmini dan beberapa video yang beredar di Youtube, Grid.id mengisahkan detail isi video viral yang beredar di masyarakat tentang aksi massa kepada pria terduga pencuri amplfier di sebuah masjid tanggal 1 Agustus 2017.

Keseluruhan isi berita, reporter (sekaligus editor) bernama Way tampaknya hanya fokus kepada pengilustrasian detail isi tayangan video viral tentang aksi massa. Diceritakan terdapat seseorang (tanpa berusaha menggali siapa profil korban) yang berlumuran darah akibat dihakimi 
massa tergeletak dipinggir jalan disaksikan banyak orang termasuk anak-anak. Dalam kondisi lemah warga mengangkat tubuh korban menuju selokan dan disaat bersamaan muncul teriakan 'matiin, matiin aja dah'. Seketika ada yang menyiramkan bensin ke tubuh korban kemudian membakarnya. Terdengar suara bernada gembira saat aksi tersebut berlangsung.

Grid.id juga menampilkan sub judul berita berjudul Ternyata Bukan Maling. Sub judul ini berisi tentang uraian bahwa MA bukan pelaku pencurian. Disebutkan bahwa terduga sedianya melakukan shalat ashar di musalah namun karena takut ampli (pengeras suara) yang bawa akan hilang jika diletakkan diatas jok motor maka ampli tersebut dibawa masuk kedalam musala. Usai shalat seseorang tersebut kemudian kembali menuju ke motor sambil membawa ampli. Disaat itulah disangka maling dari dalam masjid. Diuraikan pula bahwa MA adalah tukang servis televisi yang sedianya akan mengantar ampli ke majikannya. Berita diakhiri dengan penulisan kalimat bernada keprihatinan dari wartawan terkait profil korban aksi massa meskipun tidak ada sumber informasi yang disertakan.

Padahal dia adalah seorang tukang servis TV, yang akan mengantar ampli ke tempat majikanya. Sementara istrinya dalam keadaan hamil 7 bulan. Atas kejadian itu, pihak keluarga korban hanya bisa pasrah dan diam menerimanya.

Keluarganya orang yang tidak mampu, dan memaafkan dan tidak memperkarakanya.

Sungguh tragis nasib tukang servis itu. (*)

\section{Perbedaan frame tribunjogja.com dan grid.id}

Hasil analisis framing terhadap keseluruhan isi berita headline amuk massa yang diturunkan tribunjogja.com dan grid.id dapat ditarik simpulan. Pertama, tribunjogja.com berfokus pada pengilustrasian kebringasan amuk massa sebagaimana yang divisualisasi-kan di akun FB beberapa netizen tanpa mencari tahu fakta dilapangan yang sesungguh-nya dan hanya mengandalkan sumber kutipan wartawan dari Warta Kota.

Kedua, tribunjogja.com cenderung bertindak eksploitatif dalam menayangkan gambar foto kondisi korban dengan ukuran besar dan disertai fokus gambar wajah korban amuk massa meskipun dengan teknik blur. Di samping itu pilihan dan susuan kata-kata untuk menggambarkan kronologis kejadian juga cenderung bernuasa sadisme dan dramatis. Misalnya tewas dibakar, disiram bensin lalu dibakar hidup-hidup, tewas dengan luka bakar parah, tanpa ada yang menolong.

Ketiga, tibunjogja.com hanya menggunakan pernyataan resmi dari pihak kepolisian sebagai satu-satunya sumber informasi dalam pengungkapan peristiwa dilapangan. Padahal sumber-sumber informasi lain yang ada dilapangan patut disuguhkan untuk memenuhi unsur keberimbangan infomasi jurnalitik. Pernyataan resmi dari kepolisian pun justru dikutip dari wartawan dari Warta Kota. Mengandalkan pernyataan resmi dari aparat kepolisian adalah upaya untuk menggiring pola pikir masyarakat agar 'mengiyakan' informasi yang memiliki legitimasi tersebut. Selanjutnya, pernyataan resmi dari kepolisian sekaligus menjadi 'senjata' koreksi redaksi untuk mengklarifikasi informasi yang beredar sebelumnya bahwa MA bukan pelaku pencurian.

Hasil analisis dari keseluruhan isi berita grid.id dapat disimpulkan pertama, grid.id cenderung memfokuskan pada ulasan isi video viral yang diperoleh dari akun FB netizen (terutama dari akun FB bernama Yuni Rusmini). Seluruh rangkaian kalimat berisi tentang penggambaran kronologi amuk massa. Selain itu, penayangan 2 (dua) potongan gambar foto kondisi korban juga ditampilkan. Satu foto kondisi korban yang tewas diselokan dengan tubuh masih terbakar api dan disaksikan oleh warga. Objek gambar foto yang ditampilkan 
grid.id ini ditampilkan tanpa teknik blur. Foto kedua, dengan ukuran foto yang cukup besar ditampilkan kondisi tubuh korban tewas yang setengah telanjang dengan teknik blur dibagian alat vital.

Kedua, pilihan dan susunan kata-kata grid.id lebih bernuansa sadisme dan dramatis diantaranya pembakaran orang yang disangka maling, korban tergeletak di pinggir jalan, kepala berlumuran darah, korban masih terlihat bergerak, 'matiin-matiin, matiin aja', badannya mulai terbakar dengan api yang besar, orang-orang yang berkerumun makin bersorak dan bertepuk tangan, sungguh tragis nasib tukang servis itu.

Ketiga, grid.id tidak menyertakan sumber kutipan yang diambil dari lokasi kejadian sebagai hasil dari proses wawancara. Hasil proses wawancara dapat berfungsi sebagai cross check demi akurasi data yang diperoleh melalui pengamatan (observasi) terhadap suatu fakta kejadian ataupun fenomena.

Perbedaan gaya pengungkapan berita antara tribunjogja.com dan grid.id menunjukkan bahwa teks berita tidak bisa disamakan seperti mengcopy paste dari realitas yang riil, ia haruslah dipandang sebagai konstruksi atas realitas. Karenanya, sangat potensial terjadi peristiwa yang sama dikonstruksi secara berbeda dan pada akhirnya dampak setelah membaca beritanya pun akan berbeda. Menurut kaum konstruksionis, berita adalah hasil dari konstruksi sosial dimana selalu melibatkan pandangan, ideologi, dan nilai-nilai dari wartawan atau media (Eriyanto, 2002).

Bagaimana realitas itu dijadikan berita sangat tergantung pada bagaimana fakta itu diperoleh, dipahami dan dimaknai. Proses pemaknaan selalu melibatkan nilai-nilai tertentu sehingga mustahil berita merupakan pencerminan dari realitas yang riil. Realitas yang sama bisa jadi menghasilkan berita yang berbeda, karena ada cara pandang yang berbeda. Berita yang kita baca sudah melalui proses konstruksi (mulai dari memilih fakta, sumber, pemakaian kata, gambar/foto, sampai penyuntingan) memberi andil besar bagaimana realitas bentukan tersebut hadir dihadapan khalayak. Dengan demikian, berita aksi massa yang disuguhkan tribunjogja.com dan grid.id adalah produk konstruksi sosial media massa. Tribunjogja.com memberitakan bahwa MA adalah memang pelaku pencurian ampli masjid. Sebaliknya, Grid.id memberitakan MA adalah bukan pelaku pencurian dan korban salah sasaran amuk massa.

\section{Visualisasi Amuk Massa untuk Kepentingan Profit.}

Untuk kesekian kalinya visualisasi kekerasan, khususnya yang ditampilkan melalui akun media sosial (kemudian disebarluaskan melalui layanan unggah dan upload video seperti Youtube) menjadi bahan 'empuk' untuk dijadikan berita. Mempertontonkan video, foto ngeri, seram dan horor kini seolah menjadi aktivitas yang kian mudah bahkan latah mengakibatkan kaburnya sisi-sisi kemanusiaan. Unggahan video viral tentang aksi massa kepada terduga pencuri ampli (pengeras suara) sebuah masjid di Bekasi dijadikan bahan berita media massa diantaranya tribunjogja.com dan grid.id. Media sosial membungkus kekerasan sosial kedalam bentuk visual menjadi sebuah komoditas yang laris manis untuk dikomodifikasikan. Bentuk konkret komodifikasi kekerasan melalui suguhan detail gambar vulgar dan suara yang mencekam adalah upaya untuk menciptakan daya tarik penonton dan komentar dari netizen. Peningkatan jumlah penonton dan komentar yang cepat inilah kemudian video yang telah ditonton oleh banyak penonton mendapatkan predikat video viral.

Sesuatu yang mampu menguras emosi sering kali mendapat perhatian besar dari masyarakat. Gambar berdarah-darah, luka lebam dan air mata menjadi unsur penting yang kemudian disukai media massa untuk diangkat salah satunya video 
viral aksi amuk massa. Penggambaran isi video viral mirip penayangan reka ulang (rekonstruksi) peristiwa kriminal ditampilkan melalui penayangan gambar foto kondisi korban yang dramatis dan rangkaian kata demi kata sarkatik. Berita kejahatan kemanusiaan akhirnya tak ubahnya hiburan, seperti drama ataupun cerita yang berisi kalimat-kalimat mencekam. Vulgarnya berita kekerasan menunjukkan etika jurnalistik kerap kali dikesampingkan pekerja media. Akan tetapi tak sedikit gaya pemberitaan tersebut, media massa justru mampu meningkatkan popularitas dan mampu meningkatkan pemasukan. Sebab media massa bukan sekadar penyampai pesan namun juga ladang profit.

Selanjutnya, visualisasi kekerasan melalui tampilan gambar/foto dan serangkaian kata-kata untuk menggambarkan fakta dilapangan sesungguhnya tidak serta merta begitu saja ditampilkan oleh media massa, melainkan sudah melalui serangkaian konstruksi pekerja media yang ada di dalamnya. Ketika mengkonstruksi tentunya ada hal yang ditonjolkan dan yang dikurangi sehingga terkadang memunculkan hiper-realitas. Hiperrealitas, menurut Sosiolog Perancis Jean Baudrillard (1983; 2000) adalah suatu realitas buatan yang meniru satu realitas tertentu melalui proses pemanipulasian sehingga realitas buatan terputus hubungannya dengan realitas aslinya. Baudrillard mengungkapkan hiperrealitas adalah gejala bermunculnya berbagai realitas buatan yang lebih real daripada yang real. Bukan hanya lebih real melainkan lebih ideal dan lebih segalanya daripada yang aslinya. Hiperrealitas merupakan realitas yang melampaui dirinya sendiri karena realitas sudah direkayasa dengan citra, halusinasi, dan simulasi. Hiperrealitas berhubungan erat dengan bagaimana manusia membangun citra dan menyusun makna hidupnya sendiri dengan bercermin pada objek-objek dan realitas semu.

Hiperrealitas terjadi karena peran media massa yang telah mampu meramu kepalsuan berbaur dengan keaslian, fakta berbaur dengan rekayasa, sehingga realitas kini seolah-olah sulit ditemukan karena realitas yang disuguhkan media massa telah melampaui realitas yang sesungguhnya (hiper). Kondisi serba hiper inilah kemudian pesan yang disampaikan media massa bukanlah informasi yang netral. Melainkan informasi yang telah lebih dulu dipoles sedemikian rupa agar isi pernyataan dapat diterima dengan baik oleh pemirsanya. Praktik hiperealitas semacam ini telah disimulasikan tribunjogja.com dan grid.id.

Tribunjogja.com dan grid.id telah sama-sama menampilkan ilustrasi detail isi video viral amuk massa yang diambil dari beberapa akun FB netizen (terutama akun FB bernama Yuni Rusmini yang digunakan rujukan tribunjogja.com dan grid.id). Pengilustrasian melalui serangkaian kata-kata bernuansa sadis dan dramatis disertai potongan-potangan gambar foto kondisi korban berinisial MA. Pilihan dan susunan kata demi kata bernuansa sarkatik dan dramatis juga digunakan kedua media massa online tersebut. Meskipun dari sisi tingkat sensitifitas grid.id jauh lebih 'mengerikan' daripada tribunjogja.com

Hiperrealitas pemberitaan yang mengandung unsur kekerasan dapat menghancurkan dasar nilai-nilai kemanusiaan seseorang. Karena, menurut Haryatmoko (2007), sasarannya bisa psikologis seseorang ataupun cara berpikirnya. Ketika melalui penayangan bahasa dan gambar/foto kekerasan di media sosial kemudian diteruskan media massa, maka khalayak dapat menjadi terbiasa hidup di tengah kekerasan. Sehingga bukan tidak mungkin cara berpikir seseorang pun berubah menjadi penuh kekerasan serta menyukai bahkan memaklumi hal-hal yang berbau kekerasan hingga sadisme.

\section{Kekerasan (Simbolik) Yang 'Diwajarkan'}

Praktik sadisme yang muncul di media massa dengan memilih dan menampilkan foto blur potongan-potongan tubuh penuh darah sebagai representasi korban-korban telah menanamkan 
ingatan pembaca untuk merekam tragedi kengerian itu. Produk berita sadisme semacam inilah dalam konteks relasi komunikasi dengan relasi kekuasaan disebut dengan kekerasan dokumen (kekerasan riil).

Kekerasan dokumen merupakan penampilan gambar kekerasan yang dipahami pemirsa dengan mata telanjang sebagai dokumentasi atau rekaman fakta kekerasan di media — apakah itu ditampilkan dalam isinya (lewat tindakan pembunuhan, pertengkaran, penusukan), atau dalam situasinya (konflik, kecelakaan, peristiwa kriminal), dan lain-lain. Kekerasan dokumen tercermin pada ilustrasi detail penggambaran situasi konflik, luka, darah, dan tangis. Kekerasan dokumen dapat menciptakan efek emosional di dalam diri pemirsa (perasaan sedih, menjijikkan, antipati dan simpati). Syaratnya, relasi antara pemirsa dengan gambar yang ditayangkan haruslah sangat tepat sesuai dengan teknik presentasi (Haryatmoko, 2007: 127-128). Misalnya, tribunjogya.com menampilkan foto secara bersamaan antara foto korban amuk massa dengan foto saat jenazah MA diberangkatkan ke pemakaman. Teknik penayangan foto semacam itu diharapkan pembaca berita tidak terlalu larut dalam luapan emosi atas tindakan aksi massa maupun aksi pencurian yang dilakukan MA, namun juga ikut bersimpati terhadap apa yang dialami korban amuk massa.

Hal senada juga ditampilkan Grid.id melalui penampilan 2 (dua) foto kondisi MA yang mengenaskan terkapar di selokan yang diberikan keterangan gambar foto orang dibakar masa/Youtube. Gambar foto yang dramatis dan pilihan kata judul foto yang sensitif adalah upaya untuk membangkitkan sisi emosi pembaca yang geram terhadap tindakan tidak manusiawi tersebut.

Tenik pemilihan foto dan peletakkan foto baik tribunjogja.com maupun dan grid.id adalah upaya mengundang simpati dan keberpihakan pembaca kepada apa yang dialami MA meskipun pada akhirnya MA ditetapkan sebagai tersangka oleh kepolisian.
Cara-cara semacam ini bisa menciptakan afeksi dan simpati di dalam hati pemirsa.

Kekerasan dokumen tidak hanya terjadi dalam penampilan gambar/foto, tetapi juga dalam bentuk tulisan. Contohnya, peradilan prematur yang dilakukan media. Peradilan prematur dituangkan melalui serangkaian kalimat yang ditujukan kepada pihak tertentu yang dicurigai seolah-olah sudah menjadi terdakwa. Saksi penting sudah lebih dulu diwawancarai dan diyakini ucapannya sebelum dimintai keterangan atau kesaksian dari polisi atau jaksa (Haryatmoko, 2007: 130-131). Praktik peradilan prematur semacam ini telah dilakukan tibunjogja.com dan Grid.id. misalnya, Tribunjogja.com menampilkan keterangan *Koreksi Redaksi diakhir berita kasus amuk massa.

*Koreksi redaksi:

Keterangan dari kepolisian ini sekaligus merupakan klarifikasi atas kabar yang beredar sebelumnya yang menyebutkan bahwa MA merupakan korban amuk massa salah sasaran.

Teknik penyampaian koreksi redaksi adalah upaya tribunjogja.com untuk mengurai kesimpulan yang keliru dalam pemberitaan sebelumnya terkait status MA sebagai korban salah sasaran. Koreksi redaksi disampaikan setelah mendapatkan klarifikasi dari pihak kepolisian. Akan tetapi, pemberian keterangan koreksi redaksi semacam ini tentu tidak sebanding dengan rasa traumatik yang dirasakan oleh keluarga korban amuk massa. Pemberitaan yang ada di headline tersebut sudah terlanjur dikupas habis melalui rangkaian 19 kalimat berisi uraian detail kronologi aksi amuk massa yang 'berdarah-darah' dan hingga penggambaran foto detail kondisi korban. Sebaliknya koreksi redaksi ditampilkan hanya bermodalkan sumber resmi kepolisian berjumlah satu kalimat dan itupun diambil dari kutipan Warta Kota. 
Polisi Benarkan MA Pencuri Pengeras Suara

Namun informasi ini dibantah pihak kepolisian.

Menurut Kapolres Metro Bekasi, Kombes Asep Adi Saputra, sebagaimana dilansir Warta Kota disebutkan bahwa pria berinisial MA ini memang merupakan pencuri ampli di masjid tersebut.

"Hasil penyelidikan menyebutkan, bahwa korban yang dibakar massa ini adalah pelaku pencurian amplifire musala," ujarnya, Rabu (2/8/2017) malam.

Koreksi redaksi dimunculkan juga dimungkinkan sebagai bentuk permohonan maaf atas penyimpulan salah terkait status korban akibat kurangnya akurasinya perolehan informasi yang diambil langsung dilokasi kejadian. Permintaan maaf media semacam ini tentu juga tidak sebanding atau tidak mampu mengkompenssasi penderitaan korban (maupun keluarga korban) amuk massa karena tuduhan media yang salah tersebut. Disinilah praktik permohonan maaf, rasa bersalah bercampur aduk dengan peningkatan popularitas maupun profit. Pada akhirnya, martabat manusia sedang dilecehkan.

Peradilan prematur media yang dilakukan grid.id termanifestasikan pada uraian isi sub judul Ternyata Bukan Maling. Sub judul tersebut menjelaskan bahwa pria yang menjadi korban amuk massa adalah bukan pelaku pencurian melainkan pria yang berprofesi sebagai tukang servis televisi usai shalat ashar di masjid kemudian keluar sambil membawa ampli milikinya sendiri menuju motornya. Saat menuju motornya itulah disangka maling ampli.

\section{Ternyata Bukan Maling}

Setelah dilakukan penelusuran dan pengecekan, ternyata korban bukanlah seorang maling.

Dia sama sekali tidak mencuri.

Ternayata ampli di masjid masih utuh tidak tidak ada yang hilang.

Padahal korban saat itu selesai sholat di masjid. Korban kebetulan membawa ampli-nya sendiri ke dalam masjid karena takut hilang kalau ampli ditaruh di jok motor.

Setelah sholat, dia keluar membawa ampli yang dibawanya dari luar.

Saat itulah dia disangka maling ampli dari dalam masjid.

Padahal dia adalah seorang tukang servis TV, yang akan mengantar ampli ke tempat majikannya. Sementara istrinya dalam keadaan hamil 7 bulan. Atas kejadian itu, pihak keluarga korban hanya bisa pasrah dan diam menerimanya. Keluarganya orang yang tidak mampu, dan memaafkan dan tidak memperkarakannya.

Sungguh tragis nasib tukang servis itu. (*)

Grid.id tidak menjelaskan siapa pihak yang dimintai keterangan terkait status MA bukanlah pencuri ampli dan dimungkinkan hanya mengandalkan informasi dari para komentar netizen yang bertebaran di media sosial. Kalimat sungguh tragis nasib tukang servis itu adalah suguhan kalimat yang bernada simpatik wartawan kepada pelaku korban salah sasaran tersebut sekaligus menegaskan bahwa bukanlah pencuri.

Praktik peradilan prematur yang dilakukan Tribunjogja.com maupun Grid.id menandakan tiga fakta kegagalan dalam kinerja jurnalistik. Fakta pertama, wartawan tidak berada di tempat terjadinya peristiwa. Fakta kedua, karena tidak berada dilokasi kejadian maka wartawan memanfaatkan data akun medsos pengunggah video, komentar netizen dan pihak kepolisian sebagai sumber berita/narasumber. Fakta ketiga adalah adanya kepercayaan diri wartawan beserta editornya bahwa suara pengunggah video viral, komentar netizen maupun pernyataan dari pihak aparat memiliki informasi berharga dan dapat dipertanggungjawabkan dan dipercaya sebagai kenyataan. 
Selanjutnya, akumulasi fakta praktik kekerasan dokumen baik tribunjogja.com maupun grid.id akan melahirkan kekerasan simbolik.

Sosiolog Perancis Pierre Bourdieu menjelaskan kekerasan simbolik adalah makna, logika dan keyakinan yang mengandung bias tetapi secara halus dan samar dipaksakan kepada pihak lain sebagai sesuatu yang benar. Pemaksaan tersebut dilakukan secara halus dan samar sehingga publik tidak menyadari dan merasakannya sebagai paksaan. Dengan menyembunyikan kekerasannya, diharapkan kekerasan simbolik tersebut bisa diterima dan dipercaya oleh khalayak sebagai sesuatu yang wajar. Kekerasan simbolik merupakan praktik dominasi melalui komunikasi. Oleh karena bersifat simbolik, pemirsa tidak menyadari dirinya telah diubah menjadi korban kekerasan. Pemirsa tidak mengetahui, bahwa mereka telah dimanipulasi, dibohongi, dan bahkan dikuasai. Kekerasan simbolik ini terjadi melalui medium bahasa yang nantinya akan mempengaruhi cara berpikir, cara kerja, dan cara bertindak (Thompson, 1984; Bourdieu, 1977, 1990, 1994; Piliang, 2003; Farid, 2016 ; Haryatmoko, 2007).

Praktik kekerasan simbolik dapat ditemukan melalui beberapa praktik pemakaian bahasa sebagai strategi wacana pemarjinalisasian individu atau kelompok tertentu. Eriyanto (2001) menyebutkan ada 4 (empat) praktik pemakaian bahasa sebagai strategi wacana dari marjinalisasi, yakni dengan menghaluskan makna (eufemisme), memakai bahasa pengasaran (disfemisme), labelisasi, dan stereotipe.

Pertama, penghalusan makna (eufemisme). Kata eufemisme acapkali paling kali dipakai media massa sebagai strategi pemanfaatan gaya bahasa yang tidak menying-gung perasaan orang lain, berusaha meraih simpati pemirsa sekaligus untuk mencari rasa aman. Contohnya, frasa kekurangan pangan untuk menggantikan kelaparan; jenis kelamin untuk menggantikan alat vital ; masyarakat prasejahtera untuk menggantikan warga miskin.
Praktik eufemisme atau penghalusan makna dilakukan tribunjogja.com maupun grid.id. Diantaranya Tribunjogja.com menggunakan kata diduga yang memiliki arti disangka/dikira untuk menggantikan kata dituduh yang berarti menunjuk dan mengatakan bahwa seseorang berbuat kurang baik atau melanggar hukum. Kata disangka yang berarti diduga, dikira menggantian kata dituduh yang memiliki arti menunjuk dan mengatakan bahwa seseorang berbuat kurang baik. Kata miris yang memiliki arti risau, cemas adalah upaya untuk menggantikan kata yang sepadan namun lebih kasar misalnya tragis yang memiliki arti menyedihkan.

Kata sangat memprihatinkan yang memiliki arti bersedih hati; menyedihkan menggantikan kata sangat mengenaskan yang berarti memilukan. Kata berprofesi yang berarti bidang pekerjaan yang dilandasi pendidikan keahlian menggantikan kata bekerja yang berarti melakukan suatu pekerjaan (perbuatan), berbuat sesuatu.

Kata malang yang memiliki arti sial; bernasib buruk; celaka menggantikan kata apes yang memiliki arti sial; tidak beruntung. Kata masih utuh yang berarti sempurna; tidak rusak; tidak berubah; tidak berkurang menggantikan kata tidak hilang yang berarti masih berada ditempat, tidak berpindah. Kata nahas yang berarti sial; celaka; malang menggantikan kata sial yang berarti tidak mujur; tidak berhasil.

Tabel Sebaran Kata Eufemisme

\begin{tabular}{|c|c|}
\hline www.tribunjogja.com & www.grid.id \\
\hline $\begin{array}{c}\text { Diduga } \rightarrow \text { dituduh } \\
\text { (Judul Berita) }\end{array}$ & $\begin{array}{c}\text { Ngeri } \rightarrow \text { Sadis } \\
\text { (Judul Berita) }\end{array}$ \\
\hline $\begin{array}{c}\text { Disangka } \rightarrow \text { dituduh } \\
\text { (Paragraf ke-1) }\end{array}$ & $\begin{array}{c}\text { Miris } \rightarrow \text { Tragis } \\
\text { (Paragraf ke-2) }\end{array}$ \\
\hline $\begin{array}{c}\text { Sangat } \rightarrow \begin{array}{c|}\text { Sangat } \\
\text { mengenaskan }\end{array} \\
\text { memprihatinkan } \\
\text { (Paragraf ke-1) }\end{array}$ & $\begin{array}{c}\text { Disangka } \rightarrow \text { dituduh } \\
\text { (Paragraf ke-3) }\end{array}$ \\
\hline $\begin{array}{c}\text { Malang } \rightarrow \text { Apes } \\
\text { (Paragraf ke-2) }\end{array}$ & \\
\hline
\end{tabular}




\begin{tabular}{|c|c|}
\hline $\begin{array}{c}\text { Masih utuh } \rightarrow \text { Tidak Hilang } \\
\text { (Paragraf ke-2) }\end{array}$ & \\
\hline $\begin{array}{c}\text { Miris } \rightarrow \text { Tragis } \\
(\text { Paragraf ke-3) }\end{array}$ & \\
\hline $\begin{array}{c}\text { Berprofesi } \rightarrow \text { Bekerja } \\
(\text { Paragraf ke-3) }\end{array}$ & \\
\hline
\end{tabular}

Praktik eufemisme atau penghalusan makna juga diterapkan grid.id diantaranya kata Ngeri yang berarti terasa takut atau khawatir menggantikan kata sadis yang memiliki arti tidak mengenal belas kasih, kejam, buas, ganas, kasar. Kata miris yang memiliki arti risau, cemas adalah upaya untuk menggantikan kata yang sepadan namun lebih kasar misalnya tragis yang memiliki arti menyedihkan. Kata disangka yang berarti diduga, dikira menggantian kata dituduh yang memiliki arti menunjuk dan mengatakan bahwa seseorang berbuat kurang baik.

Disfemisme adalah gaya bahasa yang digunakan untuk mengasarkan kata, frase, klausa atau kalimat dengan tujuan tertentu (Chaer, 1995: 145). Disfemisme semata-mata bertujuan untuk merias sebuah judul dan isi berita supaya menarik perhatian pembaca seperti yang dilakukan tribunjogja.com dan grid.id.

Tribunjogja.com menggunakan kata tewas yang berarti mati untuk menggantikan kata meninggal yang memiliki arti berpulang atau menggantikan kata wafat yang berarti meninggal dunia. Kata dibakar yang berarti dipanaskan, dipanggang. Sebuah kata yang lebih tepat digunakan untuk kegiatan memasak masakan. Namun kata dibakar lebih dipilih untuk menggantikan kata diamuk atau dihakimi yang memiliki arti mendapatkan perlakuan kasar dari warga. Kata dibakar dipilih sebagai upaya mendeskripsikan perlakuan bringas massa saat itu. Dengan cara seperti ini akhirnya sisi emosional pembaca akan terpacu. Kata diamuk yang berarti kerusuhan yang melibatkan banyak orang menggantikan kata dihajar yang memiliki arti memukuli supaya jera.

Selain eufemisme dan disfemisme, tribunjogja.com juga menggunakan teknik peribahasa berupa kata tangan kosong yang berarti tanpa senjata. Tangan kosong di gunakan untuk mendeskripsikan massa melakukan aksinya dengan cara memukul, menendang, menampar dan sejenisnya secara membabi buta tanpa menggunakan senjata apapun.

Sementara disfemisme yang diterapkan Grid.id diantaranya kata pembakaran yang berarti proses, cara, perbuatan membakar untuk menggantikan kata dihakimi. Kata berlumuran. Lebih lanjut Grid.id mencoba menghadirkan ilustrasi detail bagaimana perlakuan warga kepada terduga pencuri ampli masjid melalui pilihan kata-kata terkesan sadisktik. Hal ini ditandai dengan adanya upaya pengekslopitasian kondisi korban yang diuraikan kedalam serangkain kalimat yang mampu memompa emosi pembaca. Diantaranya, dibakar hidup-hidup, pembakaran orang, tergeletak dijalan, kepala berlumuran darah, terlihat bergerak meski lemah, dibawa kepinggir selokan kering, matiinmatiin, matiin aja, badannya mulai terbakar dengan api yang besar, bersorak gembira dan bertepuk tangan. Uraian rekonstruksi bagaimana detik demi detik perlakuan warga bernuansa kengerian dan keseraman semacam ini merupakan bentuk kekerasan simbolik sebab telah melakukan eksplotasi penderitaan manusia.

\section{KESIMPULAN}

Kekerasan dihadapan media massa adalah sebuah bahan pemberitaan yang patut diulas untuk diberikan kepada khalayak luas agar meningkatkan kewaspadaan dimasyarakat. Akan tetapi, ada beberapa media massa justru terjebak kepada sikap paradoks. Dengan dalih memberitakan peristiwa apa adanya, media telah terjebak pada sebuah tindakan eksploitasi pendertiaan manusia demi 
maksimalisasi profit. Praktik semacam inilah media massa telah melakukan kekerasan simbolik. Hal inilah yang dilakukan tribunjogja.com dan grid.id.

Terdapat beberapa dasar pertimbangan mengapa peristiwa kekerasan salah satunya aksi amuk massa kepada pencui ampli masjid dijadikan berita diantaranya pertama, peristiwa kekerasan amuk massa masih sering dijumpai ditengahtengah masyarakat. Kedua, berita tentang peristiwa kekerasan masih memiliki nilai bisnis yang menguntungkan. Ketiga, adanya peluang media massa untuk mendramatisir kekerasan (hiperrealitas) sehingga lebih menarik untuk dibaca khalayak. Dan praktik menjadikan realitas riil menjadi realitas yang hiper (hiperrealitas) inilah media massa sedang melakukan kekerasan simbolik.

\section{DAFTAR PUSTAKA}

Amir Piliang, Yasraf. 2003. Hipersemiotika: Tafsir Cultural Studies Atas Matinya Makna. Bandung : Jalasutra.

Baudrillard, Jean. 1983. Simulations (trans. by Paul Foss, P. Perratton, and P. Beitchema), New York, Semiotext(e). 2000. The Vital Illusiion (ed. By julia Witwer) New York, Columbia University Press.

Bourdieu, Pierre. 1977. Outline of a Theory of Practice. Cambridge: Cambridge University Press.

1990. The Logic of Practice. Cambridge: Polity. 1995. Language and Symbolic Power. Cambridge, MA: Harvard University Press.

Chaer, Abdul dan Leonie Agustina. 1995. Sosiolinguistik: Perkenalan Awal. Jakarta: PT Rineka Cipta.

Eriyanto. 2002. Analisis Framing, Konstruksi, Ideologi, dan Politik. Yogyakarta: LKis.

Farid, Pribadi. 2016. Kekerasan Simbolik Media Massa : Kekerasan Simbolik Dalam Pemberitaan Kasus Peredaran Video Asusila di Media Massa Online: Kajian Sosiologi Komunikasi. Jurnal Sosiologi Pendidikan Humanis Vol. 2, No. 3, Desember 2016, Halaman 127-139. Malang : Universitas Negeri Malang.

Haryatmoko. 2007. Etika Komunikasi: Manipulasi Media, Kekerasan, dan Pornografi. Yogyakarta: Penerbit Kanisius.

Romli, Asep Syamsul M. 2012. Jurnalistik Online : Panduan Praktis Mengelola Media Online. Bandung : Nuansa Cendikia.

Thompson, John. B. 1984. Analisis Ideologi. Kritik Wacana Ideologi-ideologi Dunia. Terjemahan oleh Haqqul Yakin. 2003. Yogyakarta:Ircisod 